\title{
MAKALAH ANALISIS LAPORAN KEUANGAN
}

"Analisis Sumber dan Penggunaan Modal Kerja “

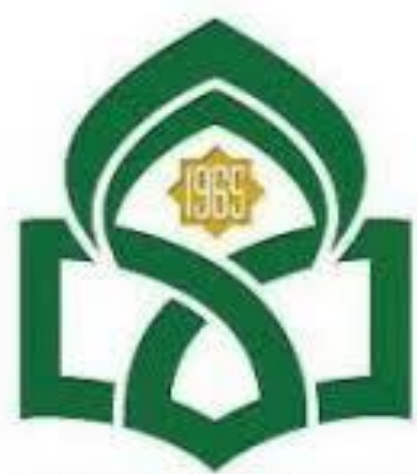

UNTVERSITAS ISLAM NEGERI

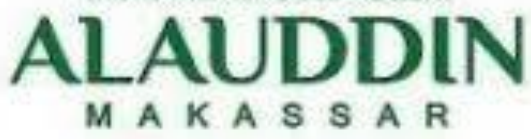

Oleh:

Kelompok VIII :

- $\quad$ Safitry (90500119065)

- Nabila Putri Islamy (90500119071)

- $\quad$ Isna Indriani (90500119089)

Dosen Pengampu :

Ismawati, S.E.,M.Si

\section{JURUSAN PERBANKAN SYARIAH \\ FAKULTAS EKONOMI DAN BISNIS ISLAM \\ UNIVERSITAS ISLAM NEGERI ALAUDDIN MAKASSAR




\section{KATA PENGANTAR}

Puji syukur Penyusun panjatkan kepada Allah S.W.T, yang telah melimpahkan rahmat, hidayah dan karunianya, sehingga penyusun dapat menyelesaikan makalah Analisis Laporan Keuangan dengan judul "Analisis Sumber dan Penggunaan Modal Kerja".

Makalah ini disusun atas dasar untuk memenuhi tugas mata kuliah Analisis Laporan Keuangan. Tidak lupa penyusun mengucapkan banyak-banyak terima kasih kepada segenap pihak yang telah membantu dan memberikan bimbingan serta arahan selama penulisan makalah ini.

Penyusun menyadari bahwa makalah ini masih jauh dalam kesempurnaan, oleh karena itu kritik dan saran yang membangun sangat penyusun harapkan demi kesempurnaan makalah ini.

Akhir kata, Penyusun mohon maaf yang sebesar-besarnya apabila dalam penyusunan makalah ini terdapat banyak kesalahan. Semoga makalah ini dapat bermanfaat khususnya bagi penyusun dan umumnya bagi para pembaca.

Makassar, 14 Oktober 2021

Kelompok 8 


\section{DAFTAR ISI}

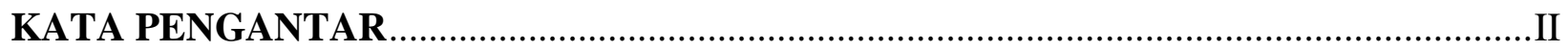

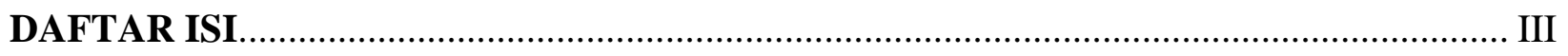

\section{BAB I}

PENDAHULUAN

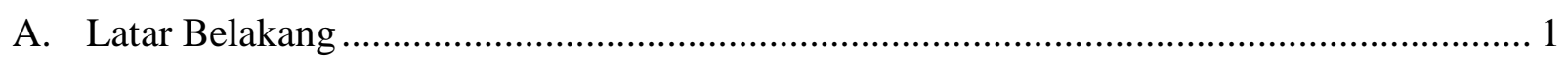

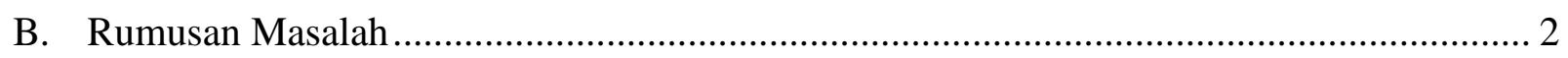

BAB II

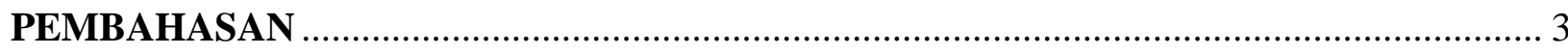

A. Pengertian Dana dan Modal Kerja ....................................................................... 3

B. Arti Penting dan Tujuan Modal Kerja ................................................................. 6

C. Faktor-faktor yang Memengaruhi Modal Kerja ................................................... 7

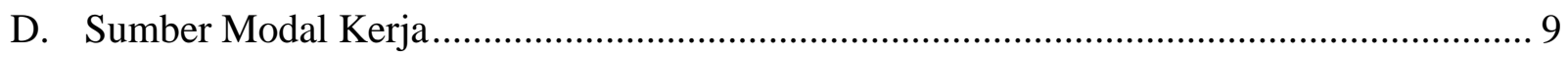

E. Penggunaan Modal Kerja........................................................................................ 10

F. Laporan Sumber dan Penggunaan Modal Kerja .................................................... 13

\section{BAB III.}

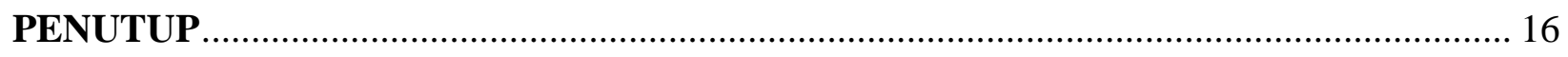

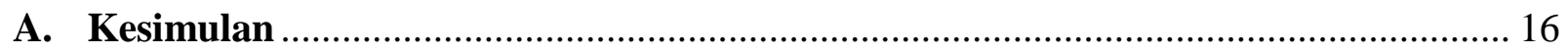

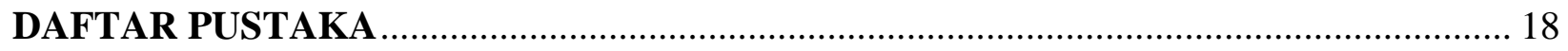




\section{BAB I}

\section{PENDAHULUAN}

\section{A. Latar Belakang}

Masalah kebutuhan modal yang akan digunakan dalam perusahaan pada dasarnya dikelompokkan menjadi dua bagian, yaitu: pertama aset modal tetap, modal yang relatif dan permanen dan akan berputar dalam jangka waktu yang lama dan diharapkan dapat mengembalikan dalam waktu singkat seperti kendaraan, kantor investasi, gedung dan lain-lain. kedua adalah aset modal kerja yang merupakan modal yang tertanam dalam unsur-unsur aset lancar seperti kas, piutang, persediaan, dan akan digunakan untuk membiayai kegiatan operasional perusahaan, seperti: pembelian bahan baku, biaya tenaga kerja, pembayaran gaji dan sebagainya.

Dimana uang atau dana tersebut dibelanjakan, itu diharapkan dapat memasukkan kembali kas ke dalam perusahaan dalam jangka pendek, umumnya tidak lebih dari satu tahun melalui penjualan barang dan jasa. Institusi-institusi yang ada tentu saja tidak dapat memisahkan diri dari perekonomian, justru ini tampaknya telah menjadi syarat penentu bagi terwujudnya setiap rencana. Apalagi jika lembaga tersebut memang tergolong lembaga yang bergerak di bidang transaksi ekonomi murni, seperti: bank, koperasi, dan lain-lain.

Dalam kedudukan ini dipahami bahwa suatu lembaga dalam mewujudkan dan menjalankan kegiatan yang direncanakan, membutuhkan modal sebagai pendukung (baik itu modal internal; dari lembaga itu sendiri, atau eksternal; modal yang bersumber dari luar/bantuan). Adanya modal yang kemudian disebut sebagai standar nilai kepemilikan suatu lembaga, juga tidak lepas dengan orientasi yang ingin dicapai. Dalam posisi ini, modal tergantung pada manajemen, bahwa di sektor apa dan bagaimana modal itu dimaksudkan untuk digunakan (apakah sektor kewajiban atau aset). Sektor kewajiban yang dimaksud adalah penggunaan modal untuk pengeluaran yang tidak disertai dengan: perhitungan pertumbuhan, sedangkan aset berkaitan dengan pemanfaatan modal disertai dengan perhitungan keuntungan pertumbuhan.

Koperasi sebagai bentuk lembaga yang terorganisir didirikan untuk membantu pertumbuhan ekonomi masyarakat dengan memanfaatkan berbagai faktor, seperti modal 
kerja, tenaga kerja dan lain-lain. Akumulasi unit-unit ini membutuhkan standar operasional dan profesionalisme untuk menjaga ritme lembaga, mengharuskan kolaborasi antar setiap komponen yang terlibat untuk membangun produktivitas peran sesuai target. Profitabilitas ekonomi (return on total assets) merupakan salah satu metode indikator untuk mengukur efisiensi dari keseluruhan penggunaan modal yang digunakan oleh suatu lembaga, serta gambaran pengelolaan perusahaan dalam pemanfaatan modal kerja yang terakumulasi dalam menghasilkan keuntungan melalui profitabilitas sendiri modal (pengembalian total kekayaan bersih).

Kunci utama dari sirkulasi ini adalah perputaran modal kerja dan penggunaan sumber daya modal secara optimal, dengan kata lain merupakan kebijakan yang tepat dalam menentukan ukuran dan tingkat profitabilitas yang diperoleh perusahaan melalui mekanisme penganggaran. Modal kerja dalam koperasi, misalnya, dapat digambarkan sebagai pengeluaran yang harus dikeluarkan untuk setiap komponen program sampai koperasi mendapat hasil.

\section{B. Rumusan Masalah}

1. Apa tujuan dari adanya modal kerja?

2. Faktor-faktor apa saja yang memengaruhi modal kerja?

3. Dari mana saja sumber modal kerja didapatkan?

4. Bagaimana penggunaan modal kerja yang efektif ? 


\section{BAB II}

\section{PEMBAHASAN}

\section{A. Pengertian Dana dan Modal Kerja}

Dalam perakteknya dana yang dimiliki oleh perusahaan, baik dana pinjaman maupun modal sendiri, dapat digunakan untuk dua hal. Pertama, digunakan untuk keperluan investasi. Artinya dana ini digunakan untuk membeli atau membiayai aktiva tetap dan bersifat jangka Panjang yang dapat digunakan secara berulang-ulang, seperti pembelian tanah, bangunan, mesin, kendaran, dan aktiva tetap lainnya. Kedua, dana digunakan untuk membiayai modal kerja, yaitu modal yang digunakan untuk pembiayaan jangka pendek, seperti pembelian bahan baku, membayar gaji dan upah, dan biaya-biaya oprasional lainnya.

Analisis sumber dan penggunaan modal kerja merupakan analisis yang berhubungan dengan sumber-sumber dana dan penggunaan dana yang berkaitan dengan

modal kerja perusahaan. Artinya dari mana saja perusahaan memperoleh dana guna membiayai kegiatannya. Kemudian, dana yang sudah diperoleh tersebut digunakan untuk aktivitas apa saja.

Perolehannya dana yang dibutuhkan perusahaan cukup banyak tersedia dan untuk memperolehnya relatif tidak terlalu sulit selama memenuhi persyaratan yang dipersyaratkan. Hanya saja dari berbagai sumber yang ada perlu diseleksi terlebih dulu. Artinya pemilihan setiap sumber dana yang akan digunakan disesuaikan dengan kebutuhan perusahaan. Di samping itu, juga perlu dipikirkan untung ruginya penggunaan sumber dana yang akan dipilih.

Dalam praktiknya pengertian dana atau fund dibagi ke dalam beberapa pengertian berikut ini.

1. Dana dianggap sebagai kas (uang tunai).

2. Dana dianggap sebagai uang yang disimpan di bank dalam bentuk giro atau tabungan.

3. Dana dianggap sebagai modal kerja.

4. Dana dianggap sebagai seluruh aktiva yang dimiliki perusahaan. 
5. Dana dianggap sebagai aktiva yang memiliki sifat sama dengan kas

Sebagai uang kas, artinya dana seperti yang tertera di dalam neraca dan langsung dapat menjadi uang tunai saat dibutuhkan. Sebagai kas dapat diartikan bahwa dana yang sesungguhnya yang dimiliki perusahaan dan siap digunakan setiap waktu dibutuhkan.

Dana sebagai uang yang disimpan di bank mengandung arti bahwa dana tersebut ditempatkan dalam bentuk simpanan. Biasanya jenis simpanan (rekening) yang dikelompokkan di sisi adalah rekening giro (demand deposit) dan rekening tabungan (saving deposit). Pertanyaannya mengapa uang yang disimpan di bank dikelompokkan sebagai dana. Hal ini disebabkan karena uang yang ada pada kedua rekening tersebut, baik giro maupun tabungan, juga dapat diambil setiap saat jika dibutuhkan melalui teller (kasir) atau ATM (Anjungan Tunai Mandiri) yang tersebar di berbagai tempat strategis. Kemudian, waktu pengambilannya pun tidak terbatas sampai 24 jam per hari dan 7 hari seminggu. Artinya uang tunai yang ada di ATM dapat diambil setiap waktu selama memenuhi persyaratan yang telah ditetapkan bank.

Dana sebagai modal kerja merupakan dana yang digunakan untuk membiayai kegiatan operasional perusahaan, terutama yang memiliki jangka waktu pendek. Sebagai modal kerja diartikan seluruh aktiva lancar atau setelah dikurangi dengan utang lancar. Dana diartikan sebagai seluruh aktiva yang dimiliki Perusahaan. Artinya seluruh harta perusahaan yang dimiliki dalam aktivanya dianggap dana perusahaan. Pengertian ini memang diangap terlalu luas. Dana dianggap sebagai aktiva yang memiliki sifat sama atau setara dengan kas. Artinya semua aktiva yang memiliki fungsi seperti kas, dapat dikatakan dana.

Pengertian modal kerja secara mendalam terkandung dalam konsep modal kerja yang dibagi menjadi tiga macam, yaitu:

1. Konsep kuantitatif,

2. Konsep kualitatif,

3. Konsep fungsional,

Konsep kuantitatif, menyebutkan bahwa modal kerja adalah seluruh aktiva lancar. Dalam konsep ini adalah bagaimana mencukupi kebutuhan dana untuk membiayai 
operasi perusahaan jangka pendek. Konsep ini sering disebut dengan modal kerja kotor (gross working capital).

Kelemahan konsep ini adalah pertama, tidak mencerminkan tingkat likuiditas perusahaan, dan kedua, konsep ini tidak mementingkan kualitas apakah modal kerja dibiayai oleh utang jangka panjang atau jangka pendek atau pemilik modal. Jumlah aktiva lancar yang besar belum menjamin margin of safety bagi perusahaan sehingga kelangsungan operasi perusahaan belum terjamin.

Konsep kualitatif, merupakan konsep yang menitikberatkan kepada kualitas modal kerja. Konsep ini melihat selisih antara jumlah aktia lancer dengan kewajiban lancer. Konsep ini di sebut modal kerja bersih atau (net working capital). Keuntungan konsep ini adalah terlihatnya tingkat likuiditas perusahaan. Aktiva lancer yang lebih besar dari kewajiban lancer menunjukkan kepercayaan pada kreditor kepada pihak perusahaan sehingga kelangsungan opeasi perusahaan akan lebih terjamin dengan dana pinjaman dari kreditor.

Konsep fungsional menekankan kepada fungsi dana yang dimiliki perusahaan dalam memperoleh laba. Artinya sejumlah dana yang dimiliki dan digunakan perusahaan untuk meningkatkan laba perusahaan. Semakin banyak dana yang digunakan sebagai modal kerja seharusnya dapat meningkatkan perolehan laba. Demikian pula sebaliknya, jika dana yang digunakan sedikit, laba pun akan menurun. Akan tetapi, dalam kenyataannya terkadang Kejadiannya tidak selalu demikian.

Dalam praktiknya secara umum, modal kerja perusahaan dibagi ke dalam dua jenis, yaitu:

1. Modal kerja kotor (gross working capital);

2. Modal kerja bersih (net working capital)

Modal kerja kotor (gross working capital) adalah semua komponen yang ada di aktiva lancar secara keseluruhan dan sering disebut modal kerja. Artinya mulai dari kas, 
bank, surat surat berharga, piutang, sediaan, dan aktiva lancar lainnya. Nilai total komponen aktiva lancar tersebut menjadi jumlah modal kerja yang dimiliki perusahaan.

Sementara itu, modal kerja bersih (net working capital) merupakan seluruh komponen aktiva lancar dikurangi dengan seluruh total kewajiban lancar (utang jangka pendek). Utang lancar meliputi utang dagang, utang wesel, utang bank jangka pendek (satu tahun), utang gaji, utang pajak, dan utang lancar lainnya. Pengertian ini sejalan dengan konsep modal kerja yang sering digunakan.

\section{B. Arti Penting dan Tujuan Modal Kerja}

Modal kerja memiliki arti yang sangat penting bagi operasional suatu perusahaan. Di samping itu, manajemen modal kerja juga memiliki tujuan tertentu yang hendak dicapai. Oleh karena itu, setiap perusahaan berusaha memenuhi kebutuhan modal kerjanya, agar dapat meningkatkan likuiditasnya. Kemudian, dengan terpenuhi modal kerja, perusahaan juga dapat memaksimalkan perolehan labanya. Perusahaan dalam kekurangan modal kerja dapat membahayakan kelangsungan hidup perusahaan yang bersangkutan, akibat tidak dapat memenuhi likuiditas dan target laba yang diinginkan. Kecukupan modal kerja juga merupakan salah satu ukuran kinerja manajemen.

Secara umum arti penting modal kerja bagi perusahaan, terutama bagi kesehatan keuangan perusahaan, yaitu sebagai berikut.

1. Kegiatan seorang manajer keuangan lebih banyak dihabiskan di dalam kegiatan operasional perusahaan dari waktu ke waktu. Ini merupakan manajemen modal kerja.

2. Investasi dalam aktiva lancar cepat dan sering kali mengalami perubahan serta cenderung labil. Sedangkan aktiva lancar adalah modal kerja perusahaan, artinya perubahan tersebut akan berpengaruh terhadap modal kerja. Oleh karena itu, perlu mendapat perhatian yang sungguh-sungguh dari manajer keuangan.

3. Dalam praktiknya sering kali bahwa separuh dari total aktiva merupakan bagian dari aktiva lancar, yang merupakan modal kerja perusahaan. Dengan kata lain, jumlah aktiva lancar sama atau lebih dari $50 \%$ datri total aktiva. 
4. Bagi perusahaan yang relatif kecil, fungsi modal kerja amat penting Perusahaan kecil, relatif terbatas untuk memasuki pasar dengan modal besar dan jangka panjang. Pendanaan perusahaan lebih mengandalkan pada utang jangka pendek, seperti utang dagang, utang bank satu tahun yang tentunya dapat memengaruhi modal kerja.

5. Terdapat hubungan yang sangat erat antara pertumbuhan penjualan dengan kebutuhan modal kerja. Kenaikan penjualan berkaitan dengan tambahan, piutang, sediaan dan juga saldo kas. Demikian pula sebaliknya apabila terjadi penurunan penjualan, akan berpengaruh terhadap komponen dalam aktiva lancar.

Kemudian, tujuan manajemen modal kerja bagi perusahaan adalah:

1. Guna memenuhi kebutuhan likuiditas perusahaan

2. Dengan modal kerja yang cukup perusahaan memiliki kemampuan untuk memenuhi kewajiban pada waktunya;

3. memungkinkan perusahaan untuk memiliki sediaan yang cukup dalam rangka memenuhi kebutuhan pelanggannya;

4. Memungkinkan perusahaan untuk memperoleh tambahan dana dari para kreditor, apabila rasio keuangannya memenuhi syarat,

5. Memungkinkan perusahaan memberikan syarat kredit yang menarik minat pelanggan, dengan kemampuan yang dimilikinya.

6. Guna memaksimalkan penggunaan aktiva lancar guna meningkatkan penjualan dan laba;

7. melindungi diri apabila terjadi krisis modal kerja akibat turunnya nilai aktiva lancar; serta

8. tujuan lainnya.

\section{Faktor-faktor yang Memengaruhi Modal Kerja}

Modal kerja yang dibutuhkan perusahaan harus segera terpenuhi sesuai dengan kebutuhan perusahaan. Namun, terkadang untuk memenuhi kebutuhan modal kerja seperti yang diinginkan tidaklah selalu tersedia. Hal ini disebabkan terpenuhi tidaknya kebutuhan modal kerja sangat tergantung kepada berbagai faktor yang memengaruhinya. 
Oleh karena itu, pihak manajemen dalam menjalankan kegiatan operasi perusahaan terutama kebijakan dalam upaya pemenuhan modal kerja harus selalu memerhatikan faktor-faktor tersebut.

Ada beberapa faktor yang dapat memengaruhi modal kerja yaitu:

1. Jenis perusahaan;

2. syarat kredit;

3. Waktu produksi;

4. tingkat perputaran sediaan.

Jenis kegiatan perusahaan dalam praktiknya meliputi dua macam, yaitu: perusahaan yang bergerak dalam bidang jasa dan nonjasa (industri). Kebutuhan modal dalam perusahaan industri lebih besar jika dibandingkan dengan perusahaan jasa Di perusahaan industri, investasi dalam bidang kas, piutang, dan sediaan relatif lebih besar jika dibandingkan dengan perusahaan jasa. Oleh karena itu, jenis kegiatan perusahaan sangat menentukan kebutuhan akan modal kerjanya.

Syarat kredit atau penjualan yang pembayarannya dilakukan dengan cara mencicil (angsuran) juga sangat memengaruhi modal kerja. Untuk meningkatkan penjualan bisa dilakukan dengan berbagai cara dan salah satunya adalah melalui penjualan secara kredit Penjualan barang secara kredit memberikan kelonggaran kepada konsumen untuk membeli barang dengan cara pembayaran diangsur (dicicil) beberapa kali untuk jangka waktu tertentu. Hal yang perlu diketahui dari syarat-syarat kredit dalam hal ini adalah:

1. Syarat untuk pembelian bahan atau barang dagangan.

2. Syarat penjualan barang

Syarat pembelian barang atau bahan yang akan digunakan untuk memroduksi barang memengaruhi modal kerja. Pengaruh nya berdampak terhadap pengeluaran kas. Jika persyaratan kredit lebih mudah, akan sedikit uang kas yang keluar, demikian pula sebaliknya, Syarat untuk pembelian bahan atau barang dagangan juga memiliki kaitannya dengan sediaan.

Kemudian, syarat penjualan berbeda dengan di atas. Dalam syarat penjualan, apabila syarat kredit diberikan relatif lunak seperti potongan harga, modal kerja yang 
dibutuhkan semakin besar dalam sektor piutang. Syarat-syarat kredit yang diberikan apakah 2/10 net 30 atau 2/10 net 60 juga akan memengaruhi penjualan kredit.

Untuk waktu produksi, artinya jangka waktu atau lamanya memroduksi suatu barang Makin lama waktu yang digunakan untuk memroduksi suatu barang, maka akan semakin besar modal kerja yang dibutuhkan. Demikian pula sebaliknya semakin pendek waktu yang dibutuhkan untuk memproduksi modal kerja, maka semakin kecil modal kerja yang dibutuhkan.

Pengaruh tingkat perputaran sediaan terhadap modal kerja cukup penting bagi perusahaan. Semakin kecil atau rendah tingkat perputaran, kebutuhan modal kerja semakin tinggi, demikian pula sebaliknya. Dengan demikian, dibutuhkan perputaran sediaan yang cukup tinggi agar memperkecil risiko kerugian akibat penurunan harga serta mampu menghemat biaya penyimpanan dan pemeliharaan sediaan.

\section{Sumber Modal Kerja}

Kebutuhan akan modal kerja mutlak disediakan perusahaan dalam bentuk apa pun. Oleh karena itu, untuk memenuhi kebutuhan tersebut, diperlukan sumber-sumber modal kerja yang dapat dicari dari berbagai sumber yang tersedia. Namun, dalam pemilihan sumber modal harus diperhatikan untung ruginya sumber modal kerja tersebut. Pertimbangan ini perlu dilakukan agar tidak menjadi beban perusahaan ke depan atau akan menimbulkan masalah yang tidak diinginkan.

Berikut ini adalah sumber modal kerja:

1. Dana dari Operasi Bisnis:

Jika arus masuk dana dari penjualan melebihi arus keluar dana untuk menutupi biaya pembelian barang dagangan dan biaya menjalankan bisnis, operasi saat ini akan menyediakan sumber dana bersih. Jika arus masuk dana dari penjualan lebih kecil dari arus keluar ini, operasi akan menghasilkan penggunaan dana bersih. Modal kerja yang disediakan oleh operasi adalah kenaikan atau penurunan bersih dalam modal kerja yang dihasilkan dari kegiatan usaha normal untuk menghasilkan pendapatan dan membayar biaya. Namun, tidak semua pengeluaran memerlukan penggunaan dana pada periode 
berjalan; oleh karena itu jumlah dana yang disediakan oleh operasi tidak sama dengan jumlah laba bersih yang diperoleh selama periode tersebut.

2. Penjualan Aset Tidak Lancar:

Sebuah bisnis dapat memperoleh modal kerja dengan menjual aset tidak lancar, seperti pabrik dan peralatan atau investasi jangka panjang, dengan imbalan aset lancar. Selama aset lancar diterima, penjualan merupakan sumber dana terlepas dari apakah aset tidak lancar dijual dengan keuntungan atau kerugian.

\section{Pinjaman Jangka Panjang}

Pinjaman jangka panjang, seperti penerbitan surat utang dan obligasi mengakibatkan peningkatan aset lancar, sehingga meningkatkan modal kerja. Pinjaman jangka pendek, bagaimanapun, tidak meningkatkan modal kerja. Ketika sebuah perusahaan meminjam uang tunai dengan kredit jangka pendek atau dengan menandatangani wesel bayar jangka pendek, modal kerja tidak berubah karena peningkatan aset lancar diimbangi dengan peningkatan kewajiban lancar dalam jumlah yang sama.

\section{Penerbitan Tambahan Modal Ekuitas:}

Penerbitan saham ekuitas tambahan menghasilkan arus masuk aset lancar, sehingga meningkatkan modal kerja. Dengan cara yang sama, investasi tambahan aset lancar oleh pemilik merupakan sumber dana dalam kepemilikan tunggal dan kemitraan.

\section{E. Penggunaan Modal Kerja}

Setelah memperoleh modal kerja yang diinginkan, tugas manajer keuangan adalah menggunakan modal kerja tersebut. Hubungan antara sumber dan penggunaan modal kerja sangat erat. Artinya penggunaan modal kerja dipilih dari sumber modal kerja tertentu atau sebaliknya. Penggunaan modal kerja akan dapat memengaruhi jumlah modal kerja itu sendiri. Seorang manajer dituntut untuk menggunakan modal kerja secara tepat, sesuai dengan sasaran yang ingin dicapai perusahaan.

\section{Pengumuman Dividen Tunai:}

Deklarasi dividen tunai menghasilkan kewajiban lancar (hutang dividen) dan oleh karena itu merupakan penggunaan dana. Harus dipahami bahwa itu adalah deklarasi dividen, bukan pembayaran dividen, yang merupakan penggunaan dana. Pembayaran dividen yang sebenarnya mengurangi aset lancar dan kewajiban lancar dengan jumlah 
yang sama dan dengan demikian tidak berpengaruh pada jumlah modal kerja. Penerbitan saham sebagai pengganti dividen tidak melibatkan distribusi aset dan, oleh karena itu, bukan merupakan penggunaan dana.

\section{Pembelian Aset Tidak Lancar:}

Pembelian aset tidak lancar, seperti pabrik dan peralatan, mengurangi aset lancar atau meningkatkan kewajiban lancar. Dalam kedua kasus, modal kerja berkurang.

\section{Pelunasan Utang Jangka Panjang:}

Modal kerja berkurang ketika aset lancar digunakan untuk membayar hutang jangka panjang. Namun, pelunasan hutang jangka pendek bukanlah penggunaan dana, karena aset lancar dan kewajiban lancar berkurang dalam jumlah yang sama.

Penggunaan dana untuk modal kerja dapat diperoleh dari kenaikan aktiva dan menurunnya passiva. Secara umum dikatakan bahwa penggunaan modal kerja biasa dilakukan perusahaan untuk:

1. pengeluaran untuk gaji, upah, dan biaya operasi perusahaan Lainnya;

2. pengeluaran untuk membeli bahan baku atau barang dagangan;

3. Menutupi kerugian akibat penjualan surat berharga,

4. Pembentukan dana;

5. Pembelian aktiva tetap (tanah, bangunan, kendaraan, mesin, Dan lain-lain);

6. Pembayaran utang jangka panjang (obligasi, hipotek, utang bank jangka panjang);

7. Pembelian atau penarikan kembali saham yang beredar,

8. Pengambilan uang atau barang untuk kepentingan pribadi; Dan

9. Penggunaan lainnya.

Arti pengeluaran untuk gaji, upah, dan biaya operasi perusahaan lainnya, perusahaan mengeluarkan sejumlah uang untuk membayar gaji, upah, dan biaya operasi lainnya yang digunakan untuk menunjang penjualan.

Maksud pengeluaran untuk membeli bahan baku atau barang dagangan, adalah pada sejumlah bahan baku yang dibeli yang akan digunakan untuk proses produksi dan pembelian barang dagangan untuk dijual kembali. 
Maksud untuk menutupi kerugian akibat penjualan surat berharga, atau kerugian lainnya adalah pada saat perusahaan menjual surat-surat berharga, namun mengalami kerugian. Hal ini akan mengurangi modal kerja dan segera ditutupi.

Pembentukan dana merupakan pemisahan aktiva lancar untuk tujuan tertentu dalam jangka panjang, misalnya pembentukan dana pensiun, dana ekspansi, atau dana pelunasan obligasi. Pembentukan dana ini akan mengubah bentuk aktiva dari aktiva Lancar menjadi aktiva tetap.

Pembelian aktiva tetap atau investasi jangka panjang seperti, pembelian tanah, bangunan, kendaraan, dan mesin. Pembelian ini akan mengakibatkan berkurangnya aktiva lancar dan timbulnya Utang lancar.

Arti pembayaran utang jangka panjang adalah adanya pembayaran utang jangka panjang yang sudah jatuh tempo seperti pelunasan obligasi, hipotek, dan utang bank jangka panjang.

Maksud pembelian atau penarikan kembali saham yang beredar adalah perusahaan manarik kembali saham-saham yang sudah beredar dengan alasan tertentu dengan cara membeli kembali, baik untuk sementara waktu maupun selamanya.

Maksud pengambilan uang atau barang untuk kepentingan pribadi adalah pemilik perusahaan mengambil barang atau uang yang digunakan untuk kepentingan pribadi, termasuk dalam hal ini adanya pengambilan keuntungan atau pembayaran dividen oleh perusahaan.

Penggunaan modal kerja di atas jelas akan mengakibatkan perubahan modal kerja, namun perubahan modal kerja tergantung dari penggunaan modal kerja itu sendiri. Dalam praktiknya modal kerja suatu perusahaan tidak akan berubah apabila terjadi.

1. pembelian barang dagangan dan bahan lainnya secara

2. pembelian surat-surat berharga secara tunai;

3. Perubahan bentuk piutang misalnya dari piutang dagang ke piutang wesel.

Dikatakan modal kerja tidak mengalami perubahan di sebabkan pembelian barang secara tunai, posisinya tetap berada diaktiva lancar, hanya berubah komponennya saja. Demikian pula dengan pembelian surat-surat berharga secara tunai tetap tidak mengubah aktiva lancar. Sementara itu, perubahan bentuk piutang misalnya dari piutang dagang ke piutang wesel juga tidak mengubah posisi utang lancar. 


\section{F. Laporan Sumber dan Penggunaan Modal Kerja}

Perolehan modal kerja dari sumber yang telah dipilih serta penggunaan modal kerja yang telah dilakukan selama operasi perusahaan perlu dibuatkan laporan sebagai bentuk pertanggungjawaban manajer keuangan. Laporan sumber dan penggunaan modal kerja menggambarkan bagaimana perputaran modal kerja selama periode tertentu. Laporan ini juga menunjukkan kinerja manajemen dalam mengelola modal kerjanya. Dalam laporan penggunaan dan sumber modal kerja akan terlihat perubahan modal kerja yang dimiliki perusahaan. Laporan perubahan modal kerja disebut juga dengan statement of fend atau statement of financial changes.

Seperti dijelaskan sebelumnya, perubahan modal kerja disebabkan oleh berbagai faktor. Perubahan yang terjadi dalam modal kerja harus dibuatkan laporannya yang kita sebut dengan nama laporan perubahan modal kerja. Dalam praktiknya laporan perubahan modal kerja menggambarkan:

1. Posisi modal kerja per periode;

2. Perubahan modal kerja;

3. Komposisi modal kerja;

4. Jumlah modal kerja yang berasal dari penjualan saham;

5. Jumlah modal kerja yang berasal dari utang jangka panjang

6. Jumlah modal kerja yang digunakan untuk aktiva tetap;

7. Jumlah aktiva tetap yang telah dijual; dan

8. Lainnya.

Untuk membuat laporan perubahan modal kerja, berikut ini disajikan contoh perbandingan neraca PT Ray Ibrahim, Tbk.

PT Ray Ibrahim, Tbk

Neraca Perbandingan

Per 31 Desember 2005 dan 2006 (dalam jutaan rupiah)

\begin{tabular}{|lc|c|c|c|c|}
\hline & \multicolumn{2}{|c|}{ Priode } & \multicolumn{2}{c|}{ Naik/ Turun } \\
\hline $\begin{array}{l}\text { Pos-pos } \\
\text { Neraca }\end{array}$ & dalam & Tahun & Tahun & Naik & Turun \\
\hline
\end{tabular}




\begin{tabular}{|l|c|c|c|c|}
\hline Aktiva lancer & & & & \\
\hline Kas & 250 & 350 & 100 & \\
\hline Surat-urat berharga & 140 & 50 & & 90 \\
\hline Piutang & 350 & 250 & & 100 \\
\hline Sediaan & 125 & 150 & 25 & \\
\hline Total Aktiva Lanca & $\mathbf{8 6 5}$ & $\mathbf{8 0 0}$ & & $\mathbf{6 5}$ \\
\hline Aktiva Tetap & & & & \\
\hline Tanah & 735 & 735 & & \\
\hline Mesin & 2.500 & 3.790 & 1.290 & \\
\hline Kendaraan & 1.500 & 1500 & & \\
\hline $\begin{array}{l}\text { Akumulasi } \\
\text { penyusustan }\end{array}$ & $(400)$ & $(925)$ & 500 & \\
\hline Total Aktiva Tetap & $\mathbf{4 . 3 3 5}$ & $\mathbf{5 . 1 0 0}$ & $\mathbf{2 . 7 9 0}$ & \\
\hline Total Aktiva & 5.200 & 6.900 & 2.720 & \\
\hline Utang Lancar & & & & \\
\hline Utang bank & 550 & 200 & & 350 \\
\hline Utang dagang & 100 & 200 & 100 & \\
\hline utang wesel & 100 & 50 & & 50 \\
\hline Total Utang Lancar & $\mathbf{7 5 0}$ & $\mathbf{4 5 0}$ & & $\mathbf{3 0 0}$ \\
\hline $\begin{array}{l}\text { Utang Jangka } \\
\text { Panjang }\end{array}$ & & & & \\
\hline Utang hipotek & 2.000 & 1.450 & & \\
\hline $\begin{array}{l}\text { Total Utang Jangka } \\
\text { Panjang }\end{array}$ & $\mathbf{2 . 0 0 0}$ & $\mathbf{1 . 4 5 0}$ & $\mathbf{( 2 0 0 )}$ & \\
\hline Ekuitas & $\mathbf{5 . 2 0 0}$ & $\mathbf{5 . 9 0 0}$ & & \\
\hline Modal setor & 2.000 & 2.500 & 500 & \\
\hline Laba ditahan & 450 & 1.500 & 1.050 & \\
\hline Total Ekuitas & $\mathbf{2 . 4 5 0}$ & $\mathbf{4 . 0 0 0}$ & $\mathbf{1 . 5 5 0}$ & \\
\hline Total Passiva & & & \\
\hline
\end{tabular}


Secara rinfkas laporan perubahan modal kerja dapatdilihat dari penjelasan berikut ini.

\begin{tabular}{|c|c|c|c|c|}
\hline \multirow[t]{2}{*}{ komponen } & \multicolumn{2}{|c|}{ Periode } & \multicolumn{2}{|c|}{ Modal kerja } \\
\hline & Tahun 2005 & Tahun 2006 & Naik & Turun \\
\hline kas & 250 & 350 & 100 & \\
\hline Surat berharga & 14 & 50 & & 90 \\
\hline piutang & 350 & 250 & & 100 \\
\hline Sediaan & 125 & 150 & 25 & 25 \\
\hline Utang bank & 550 & 200 & 350 & \\
\hline Utang dagang & 100 & 200 & & 100 \\
\hline \multirow[t]{2}{*}{ Utang wesel } & 100 & 50 & 50 & \\
\hline & & & 525 & \\
\hline \multirow{3}{*}{$\begin{array}{l}\text { Kenaikan } \\
\text { modal kerja }\end{array}$} & - & - & & \\
\hline & & & & \\
\hline & & & 525 & 525 \\
\hline
\end{tabular}

Sebagai ilustrasi untuk mengambarkan sumber modal kerja dan penggunaan modal kerja dijelaskan berikut ini:

\section{Sumber modal kerja}

1. Hasil operasional :

- Laba Rp 1.050

- Penyusutan Rp 500

$\operatorname{Rp} 1.550$

2. Penjumlahan saham

$\operatorname{Rp} 500$

Jumlah modal kerja

Rp2.050

\section{Sumber modal kerja}

1. Pembelian mesin

Rp 1.290

2. Pembayaran utang hipotek

Rp 550

Rp 1.840

Kenaikan modal kerja bersih

$$
\text { Rp } 210
$$




\section{BAB III}

\section{PENUTUP}

\section{A. Kesimpulan}

Analisiss sumber dan penggunaan modal kerja merupakan analisis yang berhubungan dengan sumber-sumber dan peng gunaan dana perusahaan. Artinya dari mana saja sumber dana dan penggunaan dana tersebut dan untuk apa? Dana atau fund dapat diartikan sebagai:

1. Kas, (uang tunai);

1. Uang yang disimpan di bank dalam bentuk giro atau Tabungan;

2. Modal kerja;

3. Seluruh aktiva yang dimiliki perusahaan;

4. Aktiva yang memiliki sifat sama dengan kas

Modal kerja perusahaan dibagi ke dalam dua jenis, yaitu:

1. Modal kerja kotor (gross working capital)

2. Modal kerja bersih (net working capital).

Modal kerja kotor (gross working capital) adalah semua komponen yang ada aktiva lancar secara total dan sering disebut modal kerja.

Modal kerja bersih (net working capital) merupakan seluruh komponen aktiva lancar dikurangi dengan seluruh total kewajiban lancar (utang jangka pendek).

Konsep modal kerja dibagi ke dalamn:

1. Konsep kuantitatif; bahwa modal kerja adalah seluruh aktiva lancar yang dimiliki perusahaan.

2. Konsep kualitatif; konsep yang menitikberatkan kepada kualitas modal kerja. Dalam konsep ini melihat selisih antara jumlah aktiva lancar dengan kewajiban lancar.

3. Konsep fungsional, menekankan kepada fungsi dana yang dimiliki perusahaan dalam memperoleh laba.

Adapun arti penting modal kerja adalah:

1. Guna memenuhi kebutuhkan likuiditas;

2. Untuk memenuhi kewajiban yang segera harus dibayar, 
3. Karena jumlahnya melebihi separuh total aktiva;

4. Memungkinkan perusahaan untuk memiliki sediaan;

5. Memungkinkan perusahaan untuk memperoleh tambahan dana;

6. Memungkinkan perusahaan memberikan syarat kredit, dan

7. Lainnya.

Sumber modal kerja yang dapat digunakan, yaitu:

1. Hasil operasi perusahaan;

2. penjualan surat-surat berharga;

3. Penjualan saham;

4. Penjualan aktiva tetap;

5. Penjualan obligasi;

6. Memperoleh pinjaman;

7. Dana hibah, dan

8. Sumber lainnya

Penggunaan modal kerja yang biasa dilakukan peperusahaan

1. Pengeluaran untuk gaji, upah;

2. Pengeluaran untuk membeli bahan baku atau barang dagangan;

3. Untuk menutupi kerugian akibat penjualan surat berharga;

4. Pembayaran dividen;

5. Pembelian aktiva tetap;

6. Pembayaran utang jangka panjang:

7. Pengambilan uang atau barang untuk kepentingan pribadi; dan

8. Penggunaan lainnya. 


\section{DAFTAR PUSTAKA}

Hasriadi (2019). Analysis Of Sources And Use Of Working Capital In Saving And Loan Cooperative Of Marga Mulia, Bila Village, Lala Bata Sub-District. Journal of Islam and Science, 6(1).https://doi.org/10.24252/jis.v6i1.12160

Esra, Martha Ayerza dan Prima Apriweni, (2002). Manajemen Modal Kerja. Jurnal Ekonomi Perusahaan. STIE IBII.

Agnes Sawir (2005), Analisis Kinerja Keuangan dan Perencanaan Keuangan Perusahaan, Edisi Kelima. Jakarta: PT. Gramedia Pustaka Utama.

Wolk et. al. 2000. Accounting Theory: A Conceptual Institusional Approach. Fifth. Edition

Kamir.2018.Analisis Laporan Keuangan. Depok ; Rajawali Pers 